\title{
Developing Positive Risk Management Culture in Public Sector: Case Study in Sunrise of Java
}

\author{
Resha Dwi Ayu Pangesti Mulyono ${ }^{1 *}$, Sudarno ${ }^{1}$, Nining Ika Wahyuni ${ }^{1}$ \\ ${ }^{1}$ Department of Accounting, University of Jember, Jember, Indonesia \\ "Corresponding author. Email: reshadwiayupm.feb@unej.ac.id
}

\begin{abstract}
The aim of this study is to develop positive risk culture in a specific Banyuwangi Government. The research results will be used to make recommendations on how to entrench risk culture so that it forms part of the organization's daily activities at all levels of operations. Building Risk Management Culture is important in order Government have Good Governance and Free Corruptions. This research used qualitative method with case study approach. Data analysis used by direct interview and observation in Banyuwangi Regency Government. The results of the study explain that building a culture of risk management awareness in a government is part of every decision making process at all levels of the organization that begins with the leadership's commitment to consider risk by making continuous, transparent communication in managing program activities, employee awareness of the importance of risk and integrating risk management in order to give the right decision, one of which is in the form reward and punishment depend high or low risk that arise in each activity program and every organization level.
\end{abstract}

Keywords: Risk Management Culture, Banyuwangi Government, Good Governance, decision making

\section{INTRODUCTION}

Globalization era demands a good institutional framework, which is able to encourage a democracy and accommodate people's aspirations to participate in development. Therefore, the key to the success of development is in a bureaucratic reform that is able to be productive and can be trusted to carry out the mandate of sustainable development. Azwar Anas's leadership as regent in Banyuwangi Regency can be one of the references and lessons learned how a regional leader is able to revolutionize the bureaucracy and successfully deliver regional development towards better welfare and people's lives. In accordance with the Banyuwangi Regent's Vision is 'The Reality Of The Independent Banyuwangi Community, Prosperous And Excellent Noble Through Improvement Economy And Human Resources Quality" and his mission is Realizing effective, clean and democratic governance through the implementation of professional, aspirational, participatory and transparent governance, Increasing togetherness and cooperation between the government, business actors and community groups to improve community welfare and Build economic independence and community welfare.

Azwar Anas as a regent of Banyuwangi in a relatively fast time was able to change the image of Banyuwangi for the better, from what was previously known as the "City of Santet" to become one of the important icons of national and international tourism. In addition, he is also able to create in directing an inclusive development policy strategy, involving the community in every development process. This inclusive leadership model is very important because in most examples of development, people's economy does not have a large portion. Not only inclusive, he creates an innovation in some sectors to support development process like Banyuwangi as a reference for the administration of government, especially in terms of the use of information technology (IT) through e-government and e-village budgeting. The importance of a technological approach in administration a government system, with this system, they do not need to conduct direct surveillance in thousands of physical projects, but just monitor it on the system.

Many appreciations and achievements who received Azwar Anas as Regeant of Banyuwangi for his innovation ideas has also received many awards, one of which has been given an Unqualified Fair Opinion for seven times in a row on accountable and transparent financial management. It has also changed many sectors of infrastructure, culture, tourism and the economy. Doing improvement must continue to be done, one of which is to minimize and map the risks of what might arise in each of these sectors. The element of risk assessment starts with looking at the compatibility between the objectives of the activity carried out with the objectives of the target, as well as the conformity with the strategic objectives set by the Government. One form that can be done by the Banyuwangi Government is to carry out risk management in each line, sector and related services and work together.

Government organizations have struggled to implement and maintain effective and efficient risk management processes. Many of the government organizations have, however, managed to establish and maintain basic risk management processes and structures. According to [1] a common challenge in government institutions is that benefits of risk management have not been realized. In Indonesia according to Government Regulation Number 60 of 2008 concerning the Government Internal Control System (SPIP) is an effort of the Government to fulfill article 58 of Law Number 1 of 2004 concerning the State Treasury, namely to implement a system of internal control in the Government as a whole in 
order to improve performance, transparency and accountability. With the application of effective internal control, it is expected to provide. Government Internal Control System (SPIP) has 5 (five) elements of control, namely: 1) Control environment, 2) Risk assessment, 3) Control activities, 4) Information and communication, and 5) Internal control monitoring.

Banyuwangi Regency Government has tried to be able to apply the rules that have been made by the Government related to Risk management. The trigger for the implementation of Risk Management in the Banyuwangi Regency Government area is the commitment of the leaders in the Banyuwangi Regency Government to prevent corruption, fulfill obligations under the Government Regulation No. 60 of 2008 and the motivation to make the Banyuwangi Regency Government environment free of corruption-free areas. The first step that can be taken is to build a culture of risk awareness in each activity and workplace in each department within the Banyuwangi Government. Risk culture is the responsibility of the board and management and that it is essential for the effective management of a business. According to [3] the adoption of a risk culture is the most important success factor for the organization when shifting from a purely risk control business model to a risk transformed organization model. The best way to comprehend the risk culture across an organization is to engage directly with the employees whose daily activities are to identify, take and manage risk [2].

The aim of this study is to develop positive risk culture in a specific Banyuwangi Government The research results will be used to make recommendations on how to entrench risk culture so that it forms part of the organization's daily activities at all levels of operations. Building a risk culture on all fronts will help improve government performance, be controlled and in accordance with the objective of being free from corruption in accordance with the KPK's direction.

\section{LITERATURE REVIEW}

\subsection{Risk Culture}

According to [10], [9] describes that risk culture is defined in different ways by an organization's characteristics and operating environment. Influential organizations such as the Institute of Risk Management refer to risk culture as a term describing the values, beliefs, knowledge, attitudes and understanding about risk shared by a group of people with a common purpose. This applies to all organizations including private companies, public bodies, governments and not-for-profits.

As stated in [6] define that "risk culture is the sum total of the strategy, organization, processes, systems, people, incentives, etc. expressed through how people think, feel and behave relative to risk and risk management". This is the central tenet of [11] who suggested that risk culture is a cognitive, dynamic concept with psychological and behavioral aspects interacting with organizational aspects such as systems, processes and structures. An effective risk culture is one that enables and rewards individuals and groups for taking the right risks in an informed manner.

\subsection{Risk Culture Aspect Models}

As organizational theorists have pointed out [13] culture influences all aspects of organizational life. Culture ultimately dictates what structures, methods and procedures can be successful in an organization. Most organizational culture theories emphasize or at least accept the fact that there is no single best organizational culture. What is good and what is bad depends always on the context. The term risk culture means show people in organizations see, understand and act related to risks. Much like organizational culture risk culture affects all risk management related aspects and ultimately affects whether risk management structures, methods and procedures will benefit or damage an organization.

The approach models can be applied to measure risk culture in an organization to self-assess in the areas of:

a. Tone at the top

1) risk leadership - clarity of direction

2) how the organization responds to bad news

b. Governance

1) the clarity of accountability for managing risk

2) the transparency and timeliness of risk information

c. Competency

1) the status, resources and empowerment of the risk function

2) risk skills - the embedding of risk management skills across the organization

d. Decision making

1) well informed risk decisions

2) appropriate risk taking rewarded and performance management linked to risk taking.
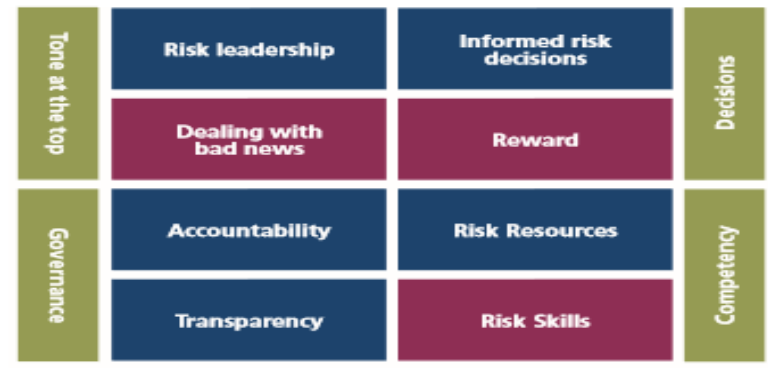

Fig 4 IRM Risk Culture Aspects Model

Source: Institute Risk Management (2012)

Figure 1 Model of Risk Culture

\subsection{Organization Culture in Government}

Organizational culture is the subject of resolving external and internal problems whose implementation is carried out consistently by a group which then bequeathed to new members as an appropriate way to understand, think and feel about related problems such as above [7]. The organizational structure that has many bodies and different locations makes 
coordination in government organizations require a good communication system and a bureaucratic system that is difficult because it refers to the hierarchy to make communication needs to be optimized. Effective communication can be a good effort in optimizing coordination and relations between agencies in government organizations. In developing organizational culture, it is almost always certain that the leadership of the organization becomes an agent of change (change agent). As an agent of change, one of the expected significant contributions is to act as a role model.

According to Regulation of The Minister Of Education Of State Applications And Bureaucratic Reform Of The Republic Of Indonesia Number 39 Of 2012 Concerning Guidelines For Development Of Work Culture described that Organizational culture within Ministries / Institutions and Local Governments can be recognized as an organizational excellence in responding to challenges and changes. Ministries / Institutions and Local Governments are expected to be able to create and develop an organizational culture oriented to improving performance, including through training, evaluating the performance of work units and employees, socializing, benchmarking, and learning laboratories. Every organization included in the government organization there is a work culture (culture set). Work culture is defined as a person's perspective in giving meaning to "work". Thus, work culture is defined as the attitudes and behaviors of individuals and groups that are based on values that are believed to be true and have become the nature and habits in carrying out daily tasks and work. In practice, work culture is derived from organizational culture. Work culture is an organizational commitment, in an effort to build human resources, work processes, and better work results. The achievement of improved quality improvement is expected to come from every individual involved in the work organization itself. Therefore, bureaucratic reform seeks to change the current work culture, into a culture that develops attitudes and results-oriented work attitudes (outcomes) obtained from high work productivity and performance.

\section{RESEARCH METHODOLOGY}

This article presents the case study as a type of qualitative research. Its aim is to give a detailed description of a case study, its definition, some classifications, and several advantages and disadvantages in order to provide a better understanding of this widely used type of qualitative approach. This paper explains how to develop positive risk management culture in government within Banyuwangi Government. A simple definition of qualitative research is not possible; therefore, a description of its purpose and characteristics is provided. As [8] described, "Qualitative researchers are interested in understanding how people interpret their experiences, how they construct their worlds, and what meaning they attribute to their experiences." The primary characteristics of qualitative research include: 1) the focus on understanding peoples' experiences with intent to convey experiences into meaning, 2) the researcher is the key instrument for data collection and analysis, 3) the research process is inductive and not deductive, and 4) the product of qualitative research is richly descriptive.
In order to obtain the expected results in this study, researchers conducted data collection by interview method directly on 20 informants in the Banyuwangi Regency Government and observation. The activity which is also the object of research is to understand the main tasks and functions of each researcher in order to obtain maximum results. The purpose of the researchers is only to convey the clearest, most comprehensible and comprehensible results which are then outlined in this article. Researchers are required to understand in terms of motives, social, individual life experiences and behavior of respondents. Then the steps taken by researchers to analyze interview data by: (a) informal conversation interviews, (b) approaches using interview general guidelines, and (c) open standard interviews. The results of the interviews were recorded with a recording aid and then processed with NVIVO software then analyzed and the conclusions drawn from the interviews.

\section{RESULTS AND DISCUSSION}

\subsection{Results}

The application of risk management is a risk management practice that has entered into everyday life. In the Government environment, risk management is important to ensure that we can achieve the best performance points set by each Government. And the most important thing is how we can also secure ourselves because there are some things related to civil law or criminal law in the effort to implement risk management by recognizing that risks will appear close to the duties and scope of work. Risk management exists to be integrated into the process of achieving organizational goals, one of which is in the District Government of Banyuwangi.

Currently the Banyuwangi Regency Regional Government has made many improvements in its organizational environment initiated by the Regent's commitment, namely Abdullah Azwar Anas, who wants that every work unit in the Banyuwangi Regional Government must be transparent, serve the public, free from corruption and work together to achieve the welfare of the Banyuwangi people. Referring to the vision and mission when elected as the Regional Head who wants to create an independent, prosperous and noble society through improving the economy and the quality of human resources by building cooperation between the government and the community. Measures of success in realizing the vision and mission can be outlined in the work program of the Regional Head, activity programs, activity reports, financial reports as a form of financial support for the implementation of activities to produce awards both at national and international level. Every activity must have inherent risks, so the thing that must be done is to minimize the risk through integrated risk management (built-in) with each other. Integration at this time is needed to get tangible results on the performance carried out. One of the efforts currently carried out by the Banyuwangi Regency Government is to build a culture of risk in each work unit of the organization. 
Building a risk culture means how an organization, especially the Regional Government, manages and responds to the risks that arise. Thus, a strong risk culture illustrates the conditions in which an organizational environment has been created which considers the importance of risk management in each unit of activity for all parties within it. There is a shared understanding of risk appetite that has been set by the Banyuwangi District Government in each regional apparatus organization (OPD). Later all decisions made by each regional apparatus are carried out by the strategic level up to the operational level always referring to the set value and the risk value that is in accordance with the organization's capacity. If the risk culture that is applied has been started through the awareness of each employee in the Banyuwangi Regency Government. If the application of this risk culture awareness is strong it can provide a competitive advantage for the Regional Apparatus Organization (OPD) within the Banyuwangi Regency Government because it can support the organization in utilizing all opportunities that can arise without worrying about the existence of harmful risks in every activity or work unit in each OPD.

Risk culture developed in the Regional Government of Banyuwangi Regency in its implementation is expected to be realized by all levels. The risk culture is manifested through the understanding and management of risk in each unit part of each decision-making process at all levels of the Regional Apparatus Organization (OPD). This form of understanding and risk management begins with the inculcation of work culture values that have been held in the Banyuwangi Regency Regional Government, namely "Banyuwangi Bahagia" which is an acronym of Banyuwangi with a moral, prosperous, beautiful and safe attitude. Where it starts from the commitment of the Regional Head, Mr. Abdullah Azwar Anas, who wants Banyuwangi Regency to be more advanced, prosperous, beautiful and safe so that the happiness of Banyuwangi people continues to increase. So, the value of the work culture that has been communicated can be sustainable to all levels of the Regional Apparatus Organization

\subsection{Discussion}

According to [5] the meaning of risk is the impact of uncertainty on organizational goals. Every action taken by the organization to achieve the goals will surely face risks. Good or bad for an organization in managing risk depends on a culture of risk that starts with attaching awareness that certain risks arise in every work program, goals and targets within the Banyuwangi District Government. A culture of risk, if well understood and applied, will have an influence in making strategic decisions and assessing their performance.

At the moment the Regional Government of Banyuwangi Regency is developing a culture of risk awareness, during field observations and interviews with several Regional Apparatus Organizations (OPDs) the trigger for holding awareness of risk is a demand that the Government environment must be free of corrupt areas where the KPK has campaigned for each Organization Regions must have high integrity and be free of corruption. Starting from the commitment of regional leaders namely the Banyuwangi
Regent, Regional Secretary, Inspectorate and Head of the Regional Apparatus Organization (tone at the top). The role of the leader becomes the main driver for starting a culture of risk care. Next will be communicated to the level of Section Chief, Sub Division Head to the lowest staff. The role of communication is very important, this will affect the behavior of employees in efforts to implement risk management in every activity and target of the organization. The spirit of building a risk management environment in the District Government of Banyuwangi is very necessary in order to realize Banyuwangi as a happy and prosperous city for the community. Synergy between Regional Apparatus Organizations and parties directly related to the Government is very much needed by giving them an understanding of how potential risks can arise and can provide both material and immaterial losses if without good risk management.

Risk response starts from within oneself (risk selfassessment) or can be trained by conducting workshops or training on risk management that starts from the top level to the bottom level, even stakeholders or partners from the Banyuwangi District Government. This is so that the party understands that related to the program of activities to be carried out, risk management can be carried out with the same standard. Risks that have the potential to arise in the Banyuwangi Regency Government are wasteful use of costs that could be indicated as potential fraud. The attraction of the potential to do so is considered to be of great benefit so they tend to ignore the warnings of the impact of the risks that occur. Regional Government Organizations that have a lot of activity programs and high expenditure costs tend to have a high risk of fraud, so later leaders must respond immediately in order to make the best decision responding to it.

Process of recognizing and assessing risk in each unit of activity can be implemented in good governance and transparent. If governance is weak, the potential for potential losses and risks generated will be even greater. The Regional Government of Banyuwangi has made improvements every year related to governance, for now things have been done such as transparency in every activity by providing online reports from planning to implementation of activities, conducting routine checks before and after assignment, internal audit processes and externally in every program of activities, reviewing every report, transparency with Government partners such as auctions and tenders, the emergence of a cashless program (non-cash movement) on each receipt and payment transaction until an online saber extortion program is made for a public complaint forum in case of brokering. For now, the Banyuwangi Regent's commitment to the community is to provide the best and fast public services, all of which can be easily obtained through online access that is integrated with each other so that monitoring can be a control for the Government and the community. All levels are responsible for all activities carried out, so that understanding related to risk is better and can immediately take precautions. Risk monitoring and reporting in every activity program or activity must always be up to date and accurate in order to also enable better decision making. The benefit is that if monitoring and reporting is done periodically, it will increasingly provide an understanding of the potential risks that can later be made to analyze the losses that occur. All information relevant to the 




Figure 2. Model of risk culture of regional government banyuwangi

\section{CONCLUSION AND SUGGESTION}

To build a positive risk management culture within the Banyuwangi District Government requires a strong commitment from the Regional Head because of the risk uncertainty that can emerge in each activity program and the demands of the KPK in order to prevent potential corruption. Risk response starts from within oneself (risk selfassessment) or can be trained by conducting workshops or training on risk management that starts from the top level to the bottom level, even stakeholders or partners from the Banyuwangi District Government. This is intended so that risk assessments at each level can be implemented in good governance and transparent. If this culture has been developed in the environment of the Regional Government of Banyuwangi Regency, carried out continuously and consistently over a long period of time, a culture of risk management can be created. If self-awareness of the importance of caring for potential risks, then every decisionmaking process at all levels of the organization will be wiser. Appreciation for them is very much needed so that risk management can be carried out properly and integrated in every process of implementing program activities.

For the good of academically and practically related to building a risk management culture in the Government environment are:

a. Ensuring that the risks in the government are then identified/ recognized and assessed for their level of significance, and an action plan has been made to minimize the impact and likelihood of these risks occurring.

b. Ensuring that if the action plan is implemented effectively, the action can minimize the impact and the possibility of risk occurrence.

c. Building a culture of risk awareness must be maintained on an ongoing basis at every level of the Organization so that conditions are created that are more transparent and responsive to what needs to be done about risks.

d. Further research can be developed related to Risk Management Culture within the Regional and Central Government environments by mapping, evaluating and evaluating the risks posed 
[5] Institute of Risk Management. (2012). Risk Culture: Under the Microscope Guidance for Boards. London: Institute of Risk Management.

[6] KPMG (2015). Risk Culture Maturity Model. KPMG Ignite.

[7] Laksmi, Asri Riani. (2011). Budaya Organisasi. Yogyakarta: Graha Ilmu

[8] Merriam S, Associates. (2016). Qualitative research in practice: examples for discussion and analysis. San Francisco, CA: Jossey-Bass.

[9] Power, M., Ashby, S. and Palermo, T. (2015). Risk Culture in Financial Organisations: A Research Report. London School of Economics.

[10] Protiviti (2014). Establishing and Nurturing an Effective Risk Culture. Protiviti, California

[11] Roschmann, A. (2014). Risk Culture: What it is and how it affects an Insurer's Risk Management. Working Paper on Risk Management and Insurance, No. 142, Institute of Insurance Economics, University of St. Gallen

[12] Regulation Of The Minister Of Education Of State Applications And Bureaucratic Reform Of The Republic Of Indonesia Number 39 Of 2012 Concerning Guidelines For Development Of Work Culture

[13] Schein, E. (2010). Organizational Culture and Leadership, 4thedition, Jossey-Bass, San Francisco, USA

[14] https://www.theirm.org/knowledge-andresources/thought-leadership/risk-culture.aspx/ accsess at 30th July 2019 